Available online at Website: http://journal.uinjkt.ac.id/index.php/valensi

\title{
Aplikasi Metode SDS-PAGE (Sodium Dodecyl Sulphate Poly Acrylamide Gel Electrophoresis) untuk Mengidentifikasi Sumber Asal Gelatin pada Kapsul Keras
}

\author{
Sandra Hermanto ${ }^{1,}$ Fahrur Rahman Saputra ${ }^{2}$, Zilhadia $^{2}$ \\ ${ }^{1}$ Program Studi Kimia FST UIN Syarif Hidayatullah Jakarta \\ ${ }^{2}$ Pragram Studi Farmasi, FKIK UIN Syarif Hidayatullah Jakarta \\ Email : hermantokimia@uinjkt.ac.id
}

Received: January 2015; Revised: February 2015; Accepted: May 2015; Available Online: August 2016

\begin{abstract}
Abstrak
Gelatin sebagai salah satu bahan utama kapsul saat ini masih menjadi permasalahan ditinjau dari aspek kehalalannya karena sebagian besar diperoleh dari sumber non-halal. Salah satu sumber penghasil gelatin adalah kolagen dari kulit dan tulang sapi atau babi. Penelitian ini bertujuan untuk mengembangkan metode analisis sumber gelatin yang digunakan pada kapsul keras dengan metode SDS-PAGE (Sodium Dodecyl Sulphate Poly Acrilamide Gel Elektrophoresis). Pada tahap awal dilakukan optimasi terhadap standar gelatin sapi dan babi yang dihidrolisis dengan pepsin pada $\mathrm{pH} 4.5$ dan suhu $60{ }^{\circ} \mathrm{C}$ selama 1 jam, 2 jam dan, 3 jam. Gelatin hasil hidrolisis selanjutnya dianalisis dengan SDS-PAGE untuk menentukan waktu hidrolisis optimal. Identifikasi fragmen gelatin hidrolisat dibandingkan berdasarkan perbedaan bobot molekulnya. Hasil hidrolisis optimum diaplikasikan untuk mengidentifikasi sumber gelatin pada beberapa sampel kapsul keras yang diperoleh dari pasaran dan dibandingkan dengan kapsul keras gelatin hasil simulasi. Hasil hidrolisis optimum selama 3 jam menunjukkan adanya pita-pita spesifik pada gelatin sapi dengan bobot molekul $15 \mathrm{kDa} ; 18,5 \mathrm{kDa} ; 33 \mathrm{kDa}$ dan $47 \mathrm{kDa}$ serta pita spesifik pada gelatin babi dengan bobot molekul $12,8 \mathrm{kDa}$; $17,3 \mathrm{kDa}, 23,7 \mathrm{kDa}$ dan $37 \mathrm{kDa}$. Hasil yang sama diperoleh pada kapsul keras sampel dengan pita-pita fragmen protein yang identik dengan standar gelatin sapi. Berdasarkan hasil analisis tersebut ketiga sampel yang diuji diduga merupakan kapsul yang terbuat dari gelatin sapi.
\end{abstract}

Kata kunci: gelatin, hidrolisis, kapsul keras, pepsin, SDS PAGE.

\begin{abstract}
Gelatin as the main ingredient of capsules is still a problem for a moslem. Most of gelatin production remains largely derived from non-halal materials. One of gelatin source is came from collagen of the skin and bones of bovine or pork. The main of study is determine the source of gelatin used in hard capsules by using SDSPAGE (Sodium Dodecyl Sulphate Gel electrophoresis Poly Acrylamide) method. In the early stages, optimization of standards bovine and pork gelatin were hydrolyzed by pepsin at $\mathrm{pH} 4.5$ and $60^{\circ} \mathrm{C}$ for 1 hour, 2 hours, and 3 hours. Gelatin hydrolyzateswere analyzed by SDS-PAGE to determine the optimal hydrolysis time. Identification of gelatin hydrolyzate fragments were carried by molecular weight. Hydrolysis time optimization throught applied to identify the source of hard gelatin capsules in the samples obtained from market and compared with the simulation of hard gelatin capsules. The results showed there were of specific bands of bovine gelatin with a molecular weight of $11,4 \mathrm{kDa} ; 34 \mathrm{kDa} ; 47 \mathrm{kDa}$ and specific bands of pork gelatin with a molecular weight of $24.7 \mathrm{kDa} ; 28 \mathrm{kDa}$; and $60 \mathrm{kDa}$. Similar results were obtained on a sample of hard capsules with bands of protein fragments that were identical to bovine gelatinstandard. Based on the results, each of the samples were tested contain of bovine gelatin respectively.
\end{abstract}

Keywords: gelatin, hydrolysis, hard capsules, pepsin, SDS PAGE.

DOI :http://dx.doi.org/10.15408/jkv.v0i0.3150 


\section{PENDAHULUAN}

Kapsul adalah sediaan yang sangat umum dikonsumsi masyarakat baik sebagai sediaan obat ataupun multivitamin. Kapsul menempati peran sentral pengembangan obat karena dianggap lebih sederhana untuk diproduksi dibandingkan dengan sediaan oral lainnya sehingga secara keseluruhan dapat mempercepat periode pengembangan obat. Kemampuan kapsul dalam hal menutupi rasa dan aroma yang kurang disukai, formulasi kapsul yang sederhana dan cenderung lebih murah serta waktu pembuatan yang lebih singkat menjadi alasan pengembangan kapsul sebagai bahan utama formulasi obat. Keuntungan lainnya adalah sediaan kapsul lebih mudah untuk ditelan dibandingkan dengan sediaan oral lainnya (Guo et al., 2006).

Dibalik segala kelebihannya, cangkang kapsul sendiri merupakan produk farmasi berbasis gelatin yang pada umumnya diproduksi dari kulit dan tulang sapi atau babi. Kapsul yang sering digunakan dalam sediaan obat dan multivitamin dengan gelatin sebagai bahan bakunya merupakan bahan impor dimana $41 \%$ dari produksi gelatin dunia bersumber dari kulit babi (Jaswir, 2007). Sebagai negara dengan mayoritas penduduk muslim permasalahan kehalalan suatu produk merupakan permasalahan yang penting. LPPOM MUI menyebutkan kurang dari $25 \%$ obat yang telah tersertifikasi halal dan hanya sekitar 30 jenis yang berbentuk kapsul. Cangkang kapsul keras kosong sendiri banyak dijual di pasar tanpa adanya keterangan akan status kehalalannya. Hal ini jelas menimbulkan kekhawatiran pada masyarakat muslim karena kapsul kosong ini banyak digunakan pada sediaan-sediaan obat herbal yang sangat mudah ditemui di masyarakat.

Permasalahan utama kehalalan kapsul terletak pada sumber gelatin sebagai bahan bakunya. Oleh karena itu analisis terhadap sumber asal gelatin pada kapsul yang beredar di pasaran sangat penting dilakukan. Beberapa penelitian telah dilakukan dengan berbagai metode seperti HPLC dengan Principal component analysis (PCR) (Nemati et al., 2004), Enzyme Linked Immunosorbent Assay (ELISA) (Venien dan Levieux, 2005) dan FTIR (Fourier transform infra red)
(Hasyim et al., 2009) . Ketiga metode di atas terbukti dapat membedakan sumber gelatin sapi dan babi, akan tetapi masing-masing metode ini memerlukan hasil yang berulang dan pengalaman karena penyiapan sampel yang sensitif dan relatif sulit (Hermanto et al., 2013).

Analisis yang dilakukan oleh Hafidz et al (2011) dengan metode SDS-PAGE menunjukkan adanya perbedaan pola pemisahan protein antara gelatin sapi dan babi namun perbedaan ini tidak terlalu spesifik. Penelitian terhadap gelatin sapi dan babi dengan metode SDS-PAGE juga telah dilakukan oleh Hermanto et al., (2013) dengan menghidrolisis gelatin secara enzimatik meggunakan pepsin pada suhu 60 ${ }^{\circ} \mathrm{C}$ dan $\mathrm{pH}$ 4.5. Hasil penelitian tersebut menunjukkan adanya pita-pita spesifik pada gelatin babi pada bobot molekul 28.6 dan $36.8 \mathrm{kDa}$ yang tidak dimiliki oleh gelatin sapi sehingga dapat digunakan sebagai acuan pembeda gelatin sapi dan babi. Namun, kedua penelitian diatas dilakukan terbatas pada gelatin murni yang belum mengalami formulasi menjadi produk yang didapati di pasar seperti kapsul keras.

Berdasarkan alasan di atas maka penelitian identifikasi sumber gelatin pada kapsul keras ini dilakukan dengan cara menghidrolisis sampel menggunakan pepsin sebelum dianalisis dengan SDS-PAGE. Penggunaan pepsin yang memiliki situs pemotongan spesifik dapat menghidrolisis protein gelatin menjadi potongan-potongan rantai polipeptida dengan sebaran berat molekul yang berbeda antara gelatin sapi dan babi dimana perbedaan ini dapat dilihat dengan analisis SDS-PAGE. Hasil ini diharapkan dapat dijadikan sebagai pertimbangan dalam menentukan status kehalalan gelatin pada produk farmasi khususnya pada kapsul keras berbasis gelatin.

\section{METODE PENELITIAN}

\section{Pengambilan Sampel}

Sampel yang digunakan adalah cangkang kapsul keras yang dibeli di Pasar Pramuka, Jakarta Timur, DKI Jakarta. Pengambilan sampel dilakukan secara acak terhadap 3 merk kapsul yang berbeda.

\section{Pembuatan Kapsul Simulasi}


Seberat 5 gram gelatin ditimbang dengan kaca arloji dan dilarutkan dalam $5 \mathrm{ml}$ air panas suhu $60{ }^{\circ} \mathrm{C}$. Gliserin $1 \mathrm{ml}$ ditambahkan dalam larutan gelatin kemudian ditambahkan pewarna sambil larutan diaduk perlahan hingga larutan homogen. Kemudian 0.125 gram $\mathrm{TiO}_{2}$ ditimbang dalam kaca arloji dan didispersikan dalam $1 \mathrm{ml}$ air kemudian dicampurkan dalam larutan gelatin. Campuran diaduk hingga $\mathrm{TiO}_{2}$ terdispersi dengan baik. Selanjutnya larutan dipindahkan dalam cetakan dan didinginkan di suhu ruangan kemudian disimpan dalam desikator.

\section{Ekstraksi Gelatin}

Sebanyak $500 \mathrm{mg}$ cangkang kapsul ditimbang dan dilarutkan dalam aquadest 5 $\mathrm{ml}$ dalam tabung reaksi dan dipanaskan dalam penangas air suhu $60{ }^{\circ} \mathrm{C}$. Larutan kapsul dipindahkan dalam tube $12 \mathrm{ml}$ dan disentrifuge dengan kecepatan $6000 \mathrm{rpm}$ selama 30 menit. Supernatant yang sudah jernih dipipet ke tube $12 \mathrm{ml}$ lainnya. Supernatan ditambah aseton 1:4 (v/v) kemudian divortex selama 1 menit. Kemudian tube disetrifuge kembali untuk mengendapkan gelatin dengan kecepatan $6000 \mathrm{rpm}$ selama 20 menit. Endapan diambil disimpan dalam cawan penguap dalam oven dengan suhu $50{ }^{\circ} \mathrm{C}$ selama 1 jam. Endapan ditimbang dan disimpan dalam suasana kering (Azira et al., 2012 dengan modifikasi).

\section{Hidrolisis Enzimatik}

Sebanyak $100 \mathrm{mg}$ gelatin dari kapsul dilarutkan dalam $5 \mathrm{~mL}$ larutan buffer asetat pH 4.5 pada gelas beker $10 \mathrm{ml}$ (selanjutnya disebut larutan 1). Kemudian $2 \mathrm{mg}$ enzim pepsin ditimbang dan dilarutkan dalam $1 \mathrm{ml}$ buffer dalam tabung reaksi (larutan pepsin). Sebanyak $1 \mathrm{ml}$ larutan 1 masing-masing dimasukkan ke dalam 3 tube $2 \mathrm{ml}$. Kemudian setiap tube ditambahkan larutan pepsin sebanyak $20 \mu \mathrm{l}$ dan diberi label 1 jam, 2 jam, dan 3 jam. Selanjutnya tube diinkubasi pada suhu $60{ }^{\circ} \mathrm{C}$ selama $1 \mathrm{jam}, 2 \mathrm{jam}$, dan $3 \mathrm{jam}$ sesuai dengan label tube. Sampel kontrol merupakan $1 \mathrm{ml}$ larutan 1 yang dimasukan dalam tube dan diinkubasi selama 1 jam tanpa ditambahkan larutan pepsin. Larutan sampel yang telah diinkubasi didinginkan pada suhu ruangan kemudian ditambahkan $\mathrm{NaOH} 0.01 \mathrm{M}$ sebanyal $200 \mu \mathrm{l}$. Sampel siap dielektroforesis (Hermanto et al., 2013 dengan modifikasi).

\section{Elektroforesis SDS-PAGE}

Larutan sampel yang telah dihidrolisis sebanyak $13 \mu \mathrm{l}$ ditambahkan buffer sample 1:1, kemudian dipanaskan pada suhu $85{ }^{\circ} \mathrm{C}$ selama 5 menit, kemudian $20 \mu$ sampel dipipet dan dimasukkan ke dalam sumuran gel akrilamid. Elektroda dipasang sesuai dengan kutubnya. Elektroforesis dijalankan pada tegangan $200 \mathrm{~V}, 15 \mathrm{~mA} / \mathrm{gel}$ selama 60 menit menggunakan alat Mini-PROTEAN Tetra Cell-BIO-RAD. Setelah Elektrophoresis, gel diwarnai dengan $0.05 \%$ (w/v) Coomassie blue R-250 dalam metanol $15 \% \quad(\mathrm{v} / \mathrm{v})$ dan asam asetat 5\% (v/v) dipanaskan pada microwave selama 15 detik kemudian diinkubasiselama 60 menit. Gel dibilas dengan direndam dalam campuran metanol 30\% dan asam asetat 10\% diinkubasi di dalam waterbath hingga 2-3 jam (Hames, 1998).

\section{Analisis Data}

Analisis data dilakukan dengan perhitungan berat molekul (BM) dari masingmasing protein yang didasarkan pada standar marker yang tersedia. Perhitungan dilakukan dengan mengukur nilai Rf (total jarak tracking dari stacking gel ke separating gel (a) dibandingkan jarak tracking dari stacking gel ke masing-masing pita protein yang terbentuk (b), kemudian dicari retardation factor (Rf) dengan membagi jarak masingmasing pita dengan jarak tracking total (b/a), selanjutnya dihitung nilai log $\mathrm{BM}$ dari masing-masing $\mathrm{Bm}$ pita marker. $\mathrm{BM}$ pita fragmen polipeptida pada sampel dihitung dengan persamaan linier $\{\mathrm{Y}=\mathrm{a}+\mathrm{bX}\}$ dimana nilai $\mathrm{Rf}$ sebagai sumbu $\mathrm{X}$ dan nilai $\log$ BM sebagai sumbu Y.

\section{HASIL DAN PEMBAHASAN}

\section{Optimasi proses hidrolisis gelatin}

Sebelum analisis dilakukan terhadap sampel kapsul, terlebih dahulu dilakukan optimasi proses hidrolisis dengan menghidrolisis gelatin murni dari gelatin sapi dan gelatin babi standar (sigma) menggunakan pepsin dengan variasi waktu 1 sampai 3 jam, variasi ini penting mengingat aktifitas pepsin tidaklah tetap (Wu et al., 2006). Hasil optimasi hidrolisis dibandingkan 
dengan menganalisis pemisahan protein gelatin murni yang telah di hidrolisis tersebut pada $\mathrm{pH} 4,5$ dan temperatur $60{ }^{\circ} \mathrm{C}$ selama 1 jam, 2 jam, dan 3 jam dengan konsentrasi gel akrilamida $12 \%$.

Variasi waktu hidrolisis dilakukan untuk melihat hasil pemisahan terbaik dari hasil hidrolisis enzimatik pepsin terhadap protein gelatin. Karena aktifitas enzim tidak tetap maka perlu dilakukan percobaan terhadap aktifitas enzim untuk melihat pemisahan yang dapat memunculkan pita spesifik dari pemisahan protein gelatin sapi atau babi. Hasil optimasi proses hidrolisis gelatin dapat dilihat pada gambar 1 .

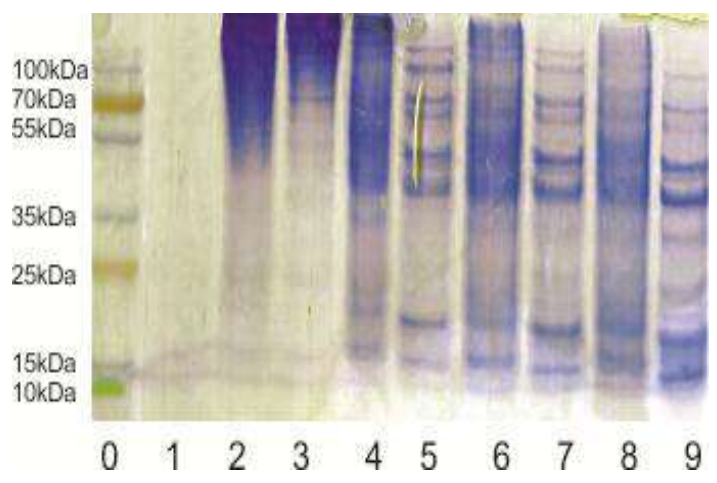

Gambar 1. Hasil elektroforesis gelatin sapi dan babi. Keterangan : (0) protein marker, (1) pepsin, (2) gelatin sapi sebelum dihidrolisis, (3) gelatin babi sebelum dihidrolisis, (4) gelatin sapi setelah dihidrolisis selama 1 jam, (5) gelatin babi setelah dihidrolisis 1 jam, (6) gelatin sapi setelah dihidrolisis selama 2 jam, (7) gelatin babi setelah dihidrolisis 2 jam, (8) gelatin sapi setelah dihidrolisis selama 3 jam, (9) gelatin babi setelah dihidrolisis 3 jam.

Dari hasil optimasi tersebut diperoleh kondisi optimum hidrolisis gelatin dengan pepsin pada $\mathrm{pH} 4.5$ dan suhu $60{ }^{\circ} \mathrm{C}$ adalah selama 3 jam. Pada waktu tersebut terlihat pita-pita fragmen peptida yang cukup jelas terutama pada kisaran 10-25 kDa dan 35-100 $\mathrm{kDa}$ dimana pada masing-masing sampel gelatin menghasilkan fragmen yang relatif berbeda. Berbeda dengan kondisi non hidrolisis, dimana pada kolom 2 dan 3, protein gelatin yang tidak dihidrolisis memilik bobot molekul yang sangat besar (diatas $55 \mathrm{kDa}$ untuk sapi dan diatas $70 \mathrm{kDa}$ untuk gelatin babi). Perbedaan pada pemisahan protein sebelum dihidrolisis ini terjadi karena gelatin yang dianalisis bukanlah merupakan gelatin yang diperoleh dengan cara ekstraksi yang sama atau dengan tipe yang berbeda. Gelatin sapi merupakan gelatin tipe B dimana pada proses ekstraksi dari kolagen asalnya menggunakan hidrolisis basa dimana bobot molekul rata-rata gelatin ini lebih besar dibandingkan bobot molekul rata-rata gelatin yang dipeloleh dari proses hidrolisis asam (tipe A) sedangkan babi merupakan gelatin tipe A (Gorgieva dan Kokol, 2011).

Selanjutnya untuk menentukan pitapita spesifik fragmen hidrolisat gelatin dilakukan perhitungan bobot molekul pada setiap fragmen dengan menghitung jarak pemisahan molekul fragmen yang dibandingkan dengan protein marker sebagai seri regresi liniernya sehingga diperoleh persamaan $\mathrm{y}=2.1569-1.1049 \mathrm{x} \quad$ dengan $\mathrm{R}^{2}=0.9903$. Dari persamaan regresi linier tersebut, bobot molekul masing-masing fragmen hidrolisat gelatin dapat dihitung sebagaimana terlihat pada tabel 1. Pada kolom 5.7, dan 9 (gambar 1) terlihat pemisahan protein gelatin babi menghasilkan 9 pita pemisahan yaitu pada BM $94.6 \mathrm{kDa}$; $74 \mathrm{kDa} ; 67.6 \mathrm{kDa} ; 51.6 \mathrm{kDa} ; 43 \mathrm{kDa} ; 33$ $\mathrm{kDa} ; \quad 23.7 \mathrm{kDa} ; \quad 17.3 \mathrm{kDa}, \quad 12.8 \mathrm{kDa}$ sedangkan pada kolom 4, 6, dan 8 merupakan protein sapi, walaupun pemisahannya belum sebaik protein babi akan tetapi sudah mulai dapat diidentifikasi seperti pita $84 \mathrm{kDa}, 70$ $\mathrm{kDa}, 58 \mathrm{kD}, 47 \mathrm{kDa}, 18.5 \mathrm{kDa}$, dan $15 \mathrm{kDa}$.

Perbedaan profil gelatin pada hasil SDS PAGE setelah dihidrolisis dapat terjadi karena urutan asam amino penyusun protein tidak sama tergantung dari spesies asalnya (Gorgieva dan Kokol, 2011). Pepsin sebagai enzim yang digunakan untuk memotong protein menjadi fragmen-fragmen rantai polipetida yang lebih pendek memiliki situssitus pemotongan yang spesifik. Pepsin memotong rantai polipeptida dengan memutus ikatan peptida yang ada pada sisi $\mathrm{NH}_{2}$ bebas dari asam-asam amino aromatik (fenilalanin, tirosin, triptofan), hidrofobik (leusin, isoleusin, metionin), atau dikarboksilat (glutamat dan aspartat) (al Janabi et al., 1972).

Hasil studi terhadap sekuen asam amino kolagen (sapi dan babi) menunjukkan terdapat banyak situs pemotongan rantai polipeptida setelah asam amino hodropobik 
seperti leusin dan fenilalanin akan tetapi

prolin dan histidin (gambar 2).

pemotongan sangat jarang terjadi setelah

Tabel 1. Jarak pita dan bobot molekul fragmen hidrolisat gelatin (hidrolisis 3 jam)

\begin{tabular}{cccc}
\hline No & Gelatin sapi $(\mathbf{m m})$ & Gelatin babi $(\mathbf{m m})$ & BM $(\mathbf{k D a})$ \\
\hline 1 & - & 7 & 94.6 \\
2 & 9 & - & 84 \\
3 & - & 11 & 74 \\
4 & 12 & - & 70 \\
5 & - & 12.5 & 67.6 \\
6 & 15 & - & 58 \\
7 & - & 17 & 51.6 \\
8 & $\mathbf{1 8 . 5}$ & - & 47 \\
9 & - & - & 37 \\
10 & $\mathbf{2 4 . 5}$ & $\mathbf{3 0}$ & 33 \\
11 & - & - & 23.7 \\
12 & $\mathbf{3 4}$ & $\mathbf{3 5}$ & 18.5 \\
13 & - & - & 17.3 \\
14 & $\mathbf{3 7 . 5}$ & $\mathbf{4 0}$ & 15 \\
15 & - & & 12.8 \\
\hline
\end{tabular}

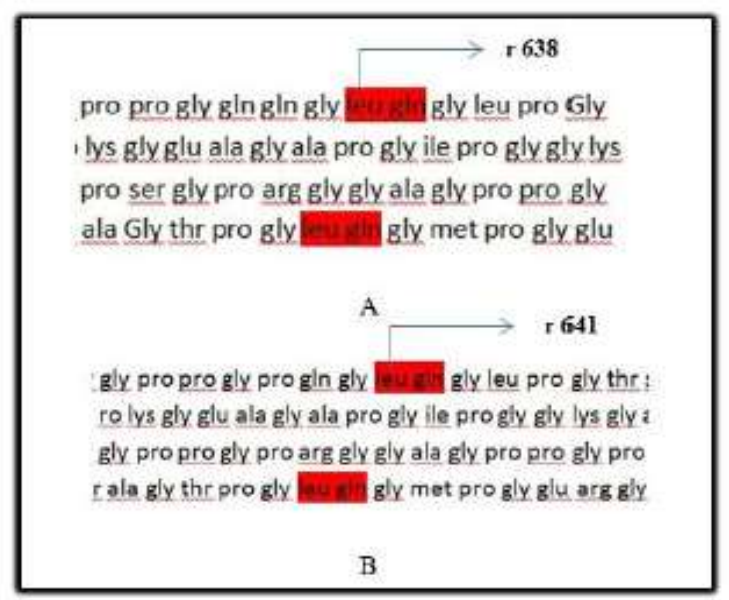

Gambar 2. Situs pemotongan pepsin pada (1) rantai alfa 1 kolagen babi, (B) rantai alfa 1 kolagen sapi (Zhang et. al., 2008).

Hasil studi (gambar 2) menunjukkan kemungkinan terjadinya pemotongan rantai polipeptida antara leusin dengan glutamin pada pH 4 adalah 100\% (Zhang et. al., 2008). Jika situs ini (leusin-glutamin) kita tempatkan ada rantai polopeptida alpha 1 dari kolagen sapi dan babi sebagai prekusor gelatin maka akan terlihat bahwa jumlah asam amino hasil pemotongan tidak akan sama jumlahnya sehingga panjang rantai polipeptida yang dihasilkan akan berbeda antara protein gelatin sapi dan babi, hal ini secara langsung mempengaruhi bobot molekul fragmen polipeptida yang dihasilkan.

\section{Identifikasi Gelatin dalam Kapsul Simulasi dan Sampel}

Setelah didapatkan kondisi optimum hidrolisis gelatin, selanjutnya dilakukan isolasi dan karakterisasi sumber asal gelatin pada produk kapsul keras yang ada di pasaran serta dibandingkan hasilnya dengan kapsul hasil simulasi gelatin sapi dan babi. Pemisahan dilakukan dengan kondisi yang sama dengan menggunakan konsentrasi resolving gel $12 \%$ dan tegangan $200 \mathrm{~V}$. Hasil pemisahan fragmen hidrolisat gelatin dari hasil isolasi dan simulasi kapsul gelatin dapat dilihat pada gambar 3 .

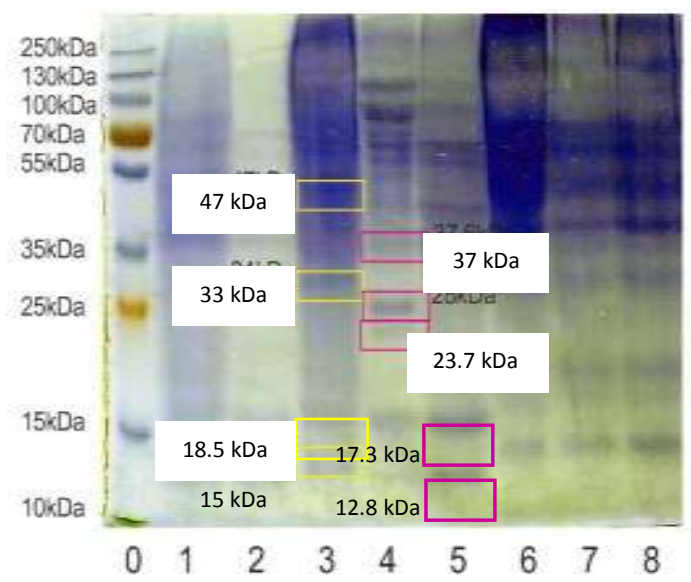

Gambar 3. Pemisahan Protein hidrolisat gelatin kapsul. Keterangan : (0) protein marker, (1) gelatin sapi murni, (2) gelatin babi murni, (3) kapsul simulasi gelatin sapi , (4) kapsul simulasi gelatin babi, (5) kapsul 
simulasi campuran gelatin sapi dan babi, (6) kapsul sampel A, (7) kapsul sampel B, (8) kapsul sampel C.

Pada kolom 5 (gambar 3) adalah kapsul simulasi yang dibuat dari campuran gelatin sapi dan gelatin babi. Kapsul ini dibuat dan disertakan dalam analisa untuk melihat bagaimana pemisahan yang terjadi jika sampel yang dianalisis merupakan gelatin campuran atau gelatin yang terkontaminasi oleh gelatin jenis lain. Pada penelitian ini diperoleh pemisahan gelatin campuran ini memiliki kemiripan dengan salah satu pemisahan dari gelatin sapi dan gelatin babi terutama pada BM di bawah 35 kDa.

Pada pemisahan gelatin campuran ini pita-pita yang merepresentasikan pita spesifik gelatin sapi sama sekali tidak muncul. Akan tetapi terdapat 2 pita spesifik dari gelatin babi yang muncul dengan bobot molekul $12.8 \mathrm{kDa}$ dan $17.3 \mathrm{kDa}$. Hal ini diasumsikan karena dalam proses hidrolisis yang terhidrolisis terlebih dahulu oleh pepsin pada campuran gelatin tersebut adalah gelatin babi, sehingga diasumsikan pada metode ini pemisahan dari gelatin kapsul yang merupakan campuran gelatin sapi dan babi tidak akan memunculkan pita spesifik gelatin sapi tetapi hanya akan memunculkan pita gelatin babi (12.8 kDa dan $17.3 \mathrm{kDa}$ ) sebagai penanda adanya kontaminasi gelatin babi pada gelatin campuran tersebut.

Setelah dilakukan analisis terhadap pita-pita pemisahan hidrolisat sampel dengan membandingkan keberadaan pita-pita spesifik pada hidrolisat gelatin sapi ataupun gelatin babi didapati bahwa pada pemisahan hidrolisat gelatin sampel 1, 2, dan 3 terdapat pita yang jelas pada BM $15 \mathrm{kDa} ; 18.5 \mathrm{kDa}$; dan $33 \mathrm{kDa}$ yang merupakan pita spesifik hidrolisat gelatin sapi dan tidak didapati keberadaan pita spesifik gelatin babi sehingga dapat disimpulkan bahwa sampel kapsul yang diteliti diduga merupakan kapsul yang dibuat dari gelatin sapi.

\section{SIMPULAN}

Dari hasil penelitian yang telah dilakukan diperoleh kesimpulan sebagai berikut:

1. Metode SDS PAGE mampu
membedakan profil hidrolisat gelatin sapi dan gelatin babi hasil hidrolisis pepsin pada $\mathrm{pH} 4.5$ dengan waktu hidrolisis optimum 3 jam.

2. Pemisahan hidrolisat gelatin sapi standar menghasilkan pita spesifik pada BM 47 $\mathrm{kDa} ; 33 \mathrm{kDa} ; 18.5 \mathrm{kDa}$ dan $15 \mathrm{kDa}$, sedangkan hidrolisat gelatin babi menghasilkan pita spesifik pada BM 37 $\mathrm{kDa} ; 23,7 \mathrm{kDa}$; dan $17.3 \mathrm{kDa}$ dan 12.8 $\mathrm{kDa}$.

3. Berdasarkan hasil uji terhadap ketiga sampel dapat diprediksi bahwa gelatin yang digunakan dalam pembuatan kapsul sampel diduga berasal dari gelatin sapi.

\section{SARAN}

Perlu diadakan analisis lebih lanjut pada pita-pita hasil pemisahan SDS PAGE dengan menggunakan LCMS sehingga dapat diketahui urutan rantai asam amino pada masing-masing pita tersebut.

\section{DAFTAR PUSTAKA}

al-Janabi J, JA Hartsuck, et al. 1972. Kinetics and mechanism of pepsinogen activation. $J$ Biol Chem. 247: 4628-32.

Azira, T., Amin. I., and Che Man, Y. B., 2012. Differentiation of bovine and porcine gelatins in processed products via Sodium Dodecyl Sulphate-Polyacrylamide Gel Electrophoresis (SDS-PAGE) and principal component analysis (PCA) techniques. International Food Research Journal 19 (3): 1175-1180.

Gorgieva, S., Kokol, V. 2011. Collagen- vs. Gelatine-Based Biomaterials and Their Biocompatibility: Review and Perspectives, Biomaterials Applications for Nanomedicine, Prof. Rosario Pignatello (Ed.), ISBN: 978-953-307-661-4.

Guo T, Zhao J, Chang J, Ding Z, Hong H, Chen J, Zhang J. 2006. Porous chitosan gelatin scaffold containing plasmid DNA encoding transforming growth factor- $\alpha 1$ for chrondrocytes proliferation. Biomaterials. 27(7): 1095-1103.

Hafidz RN, Yaakob CM, Amin I, Noorfaizan A. 2011. Chemical and functional properties of bovine and porcine skin gelatin. International Food Research Journal. 18: 813-817. 
Hashim DM, Che Man YB, Norakasha R, Shuhaimi M, Salmah Y, Syahariza YB. 2010. Potential use of fourier transform infrared spectroscopy for differentiation of bovine and porcine gelatins. Food Chemistry. 118: 856-860.

Hames BD. 1998. Gel Electrophoresis of Proteins. New York (USA): Oxford university press.

Hermanto S, Sumarlin LO, FatimahW. 2013. Differentiation of bovine and porcine gelatin based on spectroscopic and electrophoretic analysis. Journal food pharmaceutical sciences. 68-73.

Hidaka S, SY Liu. 2002. Effect of gelatins on calcium phosphate precipitation: a possible application for distinguishing bovine bone gelatin from porcine skin gelatin. Journal of Food Composition and AnalysisI. 16: 477-483.

James MN, AR Sielecki. 1986. Molecular structure of an aspartic proteinase zymogen, porcine pepsinogen, at $1.8 \mathrm{~A}$ resolution. Nature. 319(6048): 33-8.
Jaswir, I. 2007. Memahami Gelatin, didownload dari www.beritaiptek.com, 7 Juni 2012.

Nemati M, Oveisi MR, Abdollahi H, Sabzevari O. 2004. Differentiation of bovine and porcine gelatins using principal component analysis. Journal of Pharmaceutical and Biomedical Analysis. 34: 485-492.

Venien A, Levieux D. 2005. Differentiation of bovine from porcine gelatins using polyclonal anti-peptide antibodies in indirect and competitive indirect ELISA. Journal of Pharmaceutical and Biomedical Analysis I. 39: 418-424.

Wu Y, Kaveti S. 2006. Extensive deuterium backexchange in certain immobilized pepsin columns used for H/D exchange mass spectrometry. Anal Chem 78: 1719-23.

Zhang GF, Liu T, Wang Q, Lei JD, Ma GH, Su ZG. 2008. Identification of marker peptides in digested gelatins by high performance liquid chromatography/mass spectrometry. Chinese Journal of Analytical Chemistry. 36: 1499-504. 